(c) American Dairy Science Association, 2007.

\title{
Effects of Management and Genetics on Udder Health and Milk Composition in Dairy Cows
}

\author{
W. Ouweltjes, ${ }^{1}$ B. Beerda, J. J. Windig, M. P. L. Calus, and R. F. Veerkamp \\ Animal Sciences Group of Wageningen UR, Division of Animal Production, P.O. Box 65, 8200 AB Lelystad, The Netherlands
}

\begin{abstract}
Milk production per cow has increased significantly as a result of breeding, feeding, and other management factors. This study aims to address concerns about udder health risks for low- and high-producing dairy cows. In a $2 \times 2 \times 2$ factorial design, Holstein-Friesian heifers $(\mathrm{n}=100)$ of low or high genetic merit for milk production, milked 2 or 3 times a day, and fed a mixed ration with low or high energy content, were compared during the first $14 \mathrm{wk}$ of lactation. Milk composition and cell counts were determined weekly; quarter milk samples for bacteriology were taken in wk 2,8 , and 14 ; and teat condition was scored in wk 2, 6, 10, and 14 during the experiment. The experimental factors resulted in substantial differences in milk production between treatment groups ( 24.1 for low vs. $25.6 \mathrm{~kg} / \mathrm{d}$ for high genetic merit; 23.3 for 2 times vs. $26.5 \mathrm{~kg} / \mathrm{d}$ for 3 times daily milking; and 20.9 for low-energy ration vs. 29.0 $\mathrm{kg} / \mathrm{d}$ for high-energy ration). Ration composition was the most important determining factor for milk production, but did not affect cell counts or intramammary bacterial infections, although cows that received lowenergy rations had rougher teat ends than cows receiving high-energy rations. This indicates that high production itself is not a major risk factor for udder health in the first lactation. A higher milking frequency impaired teat condition and improved cell counts in general, but did not clearly influence bacteriological status. High genetic merit was related to higher cell count, more Staphylococcus, and less Bacillus and other environmental pathogens in cultures and did not affect teat condition. The effects of milking frequency and feeding on udder health were similar for cows with high and low genetic merit. Genetic selection on milk production, without taking udder health into account, reduces udder health. As a result, maintaining udder health will require increasing the skills and time of dairy farmers who have to divide their attention to more cows when
\end{abstract}

Received June 2, 2006.

Accepted August 11, 2006.

${ }^{1}$ Corresponding author: Wijbrand.Ouweltjes@wur.nl farm sizes increase, or selection should put more emphasis on udder health traits.

Key words: milk production, udder health, genetic merit, herd management

\section{INTRODUCTION}

The Dutch dairy industry has successfully increased milk production per cow per lactation during the last decades (NRS, 2004). Due to the high heritability of milk production traits and effective milk recording schemes, genetic improvement has contributed significantly to this development. Moreover, improvements in feeding (including roughage harvesting and conservation), housing, and other management aspects have contributed to the increase in milk production. Farm size in the Netherlands is increasing, which means that farmers spend less time in management per cow. This has increased the importance of health and fertility. The high economic value of longevity (van der Beek, 2000) makes fertility, udder health, and feet and leg disorders more important, as these are major reasons for culling (Beaudeau et al., 1993).

There are several examples that reveal negative effects of breeding for high milk production on health and fertility traits (Veerkamp et al., 2003; Dillon et al., 2005; Oltenacu and Algers, 2005). It is not clear to what extent the increase in phenotypic milk production can account for these negative effects. If the causal relationship is due to the increase in production, then it might be that the negative effects of selection disappear at lower production levels, whereas they might be exacerbated at higher production levels. Alternatively, many health and fertility problems are, at least partly, ascribed to negative energy balances in early lactation (Ingvartsen et al., 2003). If the effects of selection are caused by energy balance, then management factors associated with negative energy balance might interact with genetic merit for milk production. Whether genotype $\times$ environment interactions $(\mathbf{G} \times \mathbf{E})$ exist from the perspective of animal health is as yet unclear. This question is addressed in an experiment in which Holstein-Friesian heifers $(\mathrm{n}=100)$ with high $(\mathbf{H})$ or low (L) genetic merit for milk, fat, and protein production were compared for an array of health indicators under 


\begin{tabular}{|c|c|c|}
\hline \multicolumn{2}{|l|}{ FEEDING LANE } & FEEDING LANE \\
\hline $\begin{array}{c}\text { High energy ration (E) } \\
2 \times \text { daily milking }\end{array}$ & & $\begin{array}{c}\text { High energy ration (E) } \\
3 \times \text { daily milking }\end{array}$ \\
\cline { 1 - 1 } $\begin{array}{c}\text { Low energy ration (S) } \\
3 \times \text { daily milking }\end{array}$ & & Low energy ration (S) \\
& & $2 \times$ daily milking \\
FEEDING LANE & & FEEDING LANE \\
\hline
\end{tabular}

Figure 1. Description of the experimental barn.

4 different conditions; that is, 4 combinations of milking frequency ( 2 or 3 times daily) and feed quality (high or low energy density). These experimental factors were selected to create substantial differences in milk production levels. Beerda et al. (2007) demonstrated that large differences in milk production were created and that heifers milked 3 times daily had a more negative energy balance (EB) than those milked twice daily. The high-energy density diet resulted in less negative EB than did the low-energy density diet. Genetic merit did not significantly influence EB, although in the groups that received the low-energy ration, the H-heifers tended to have a more negative EB than did the Lheifers.

The aim of this study was to estimate possible risks of these changes in milk production and EB for udder health. The hypothesis was that imbalances between management and genetics increase the risk of impaired animal health at high milk production levels.

\section{MATERIALS AND METHODS}

\section{Experimental Design}

In a $2 \times 2 \times 2$ factorial design, Holstein-Friesian heifers $(n=100)$ of high $(H)$ or low $(L)$ genetic merit for milk production were milked either 2 or 3 times daily and fed a mixed ration with either high $(\mathbf{E})$ or low $(\mathbf{S})$ energy content. Group size was 11 for L groups and 14 for $\mathrm{H}$ groups. The experiment encompassed the first 14 wk of lactation, and was carried out at the research farm Nij Bosma Zathe, Goutum, the Netherlands.
In each of the 4 treatment groups, $\mathrm{H}$ and $\mathrm{L}$ heifers were kept under the same management conditions. Each compartment in the experiment could house 16 heifers (Figure 1). The ad libitum TMR intake was registered individually with a roughage intake control system manufactured by Insentec (Marknesse, the Netherlands). Individual concentrate intake was recorded by automated concentrate feeders. Heifers entered and exited the experiment individually; the experiment started in May 2003 and ended in December 2004. During the experiment the compartments housed heifers that participated in the experiment and nonexperimental animals. Heifers milked $2 \times / \mathrm{d}$ were milked at 0600 and $1700 \mathrm{~h}$; heifers milked $3 \times / \mathrm{d}$ were milked at 0600 , 1400 , and $2200 \mathrm{~h}$. The available heifers were randomly assigned to 1 of the 4 treatments. Experimental groups were designated by frequency of milking ( 2 or 3 ), energy density of ration ( $\mathrm{E}$ or $\mathrm{S})$, and genetic merit group $(\mathrm{H}$ or L) to give 8 treatment designations: 2EH, 2EL, 2SH, 2SL, 3EH, 3EL, 3SH, and 3SL.

\section{Animal Selection}

The majority of the animals used in the experiment were purchased from commercial dairy farms in the Netherlands between $1 \mathrm{wk}$ and 6 mo before their first calving, and 2 animals were born and raised on the experimental farm. Animals were selected based on 2 criteria, an expected breeding value for "Inet" of $<35$ (L) or $>110(\mathrm{H})$ and a minimum of $87.5 \%$ Holstein-Friesian pedigree. Inet is the Dutch production index for milk, fat, and protein and is calculated as: $0.06 \times \mathrm{EBV} \mathrm{kg}$ of 
Table 1. Characteristics of experimental genetic groups

\begin{tabular}{|c|c|c|}
\hline & $\begin{array}{l}\text { Low genetic } \\
\text { merit }\end{array}$ & $\begin{array}{l}\text { High genetic } \\
\text { merit }\end{array}$ \\
\hline Number of animals & 44 & 56 \\
\hline Number of sires & 31 & 24 \\
\hline Number of herds of origin & 32 & 36 \\
\hline EBV $\mathrm{kg}$ of milk ${ }^{1}$ & $-68 \pm 316$ & $771 \pm 443$ \\
\hline EBV kg of fat ${ }^{1}$ & $-7 \pm 10$ & $38 \pm 11$ \\
\hline EBV kg of protein ${ }^{1}$ & $-3 \pm 6$ & $33 \pm 7$ \\
\hline EBV inet ${ }^{1,2}$ & $-24 \pm 34$ & $171 \pm 25$ \\
\hline
\end{tabular}

${ }^{1}$ Values are mean $\pm \mathrm{SD}$.

${ }^{2} \mathrm{EBV}$ inet $=0.06 \times \mathrm{EBV} \mathrm{kg}$ of milk $+0.7 \times \mathrm{EBV} \mathrm{kg}$ of fat $+4.2 \times$ EBV $\mathrm{kg}$ of protein. Inet is the Dutch production index for milk, fat, and protein.

milk $+0.7 \times \mathrm{EBV} \mathrm{kg}$ of fat $+4.2 \times \mathrm{EBV} \mathrm{kg}$ of protein. Inet is expressed in euros $(€)$. The average reliability of breeding values of sires and maternal grandsires was $95 \%$. Measures were taken to reduce the risk of introducing novel pathogens into the research herd. Heifers were purchased from farms that had demonstrable low risks for harboring paratuberculosis, leptospirosis, or infectious bovine rhinotracheitis (IBR), as evidenced by certificates from specific disease eradication and prevention programs. Blood samples were collected from candidate experimental heifers and screened for possible infections with IBR, bovine viral diarrhea, leptospirosis, and Salmonella. Heifers that showed signs of disease, including skin lesions and leg or claw disorders, were barred from the research farm. The availability of animals that fulfilled these criteria was a limiting factor for the experiment, especially for animals with low expected genetic merit. One hundred six heifers entered the experiment, but 6 were excluded from the final analysis (Beerda et al., 2007). Results are based on 56 animals with high expected genetic merit and 44 with low expected genetic merit (Table 1). The realized average difference in EBV between both groups was $€ 195$ Inet, which represents more than $10 \mathrm{yr}$ of selection (NRS, 2004).

\section{Ration Composition}

Both rations (E and S) were fed as a basic TMR (Table 2) with additional concentrates fed in the milking parlor $(1.2 \mathrm{~kg} / \mathrm{d})$ and concentrate feeders $(1.8 \mathrm{~kg} / \mathrm{d}$ for the $\mathrm{S}$ ration and $6.8 \mathrm{~kg} / \mathrm{d}$ for the $\mathrm{E}$ ration).

The $\mathrm{E}$ and $\mathrm{S}$ rations were designed to be comparable to rations on intensive Dutch farms with high-quality roughage and rations on extensive Dutch farms with fibrous roughage, respectively. The key difference between the rations was energy density. The higher energy density of the E ration was achieved by using a high percentage of corn silage and less fibrous grass silage in the $\mathrm{E}$ ration.
Table 2. Composition of experimental rations ${ }^{1}$

\begin{tabular}{lcc}
\hline & $\begin{array}{l}\text { High } \\
\text { energy } \\
\text { ration }\end{array}$ & $\begin{array}{l}\text { Low } \\
\text { energy } \\
\text { ration }\end{array}$ \\
\hline TMR components (\% DM of total TMR) & & \\
Corn silage & 49 & - \\
Grass silage & 30 & 86 \\
Soy/customized meals & 21 & - \\
Concentrates & - & 14 \\
TMR supply & Ad libitum & Ad libitum \\
TMR DM, g/kg of product & 377 & 451 \\
TMR NE, MJ/kg DM & 6.5 & 5.9 \\
TMR DVE,, g/kg DM & 77.5 & 65.0 \\
TMR OEB, , g/kg DM & 7.4 & 7.3 \\
Concentrate supply, kg/d & 8 & 3 \\
Concentrate DM, g/kg of product & 877 & 881 \\
Concentrate NE, MJ/kg of DM & 7.5 & 7.4 \\
Concentrate DVE, g/kg of DM & 119 & 112 \\
Concentrate OEB, g/kg of DM & 27 & 47 \\
\hline
\end{tabular}

${ }^{1} \mathrm{DVE}=$ True protein digested in the small intestine; $\mathrm{OEB}=$ degraded protein balance (Beerda et al., 2007).

\section{Data Collection}

Milk composition, including fat, protein, lactose, and urea, and SCC were determined weekly in samples from 2 consecutive days in the Dutch routine laboratory for milk recording. In wk $2,6,10$, and 14 , teat condition [teat-end roughness (yes or no) and teat-end callosity (scale 1 to 5)] was scored as described by Neijenhuis et al. (2000). Furthermore, diseases and treatments were recorded if they occurred. Quarter milk samples for bacteriological culturing were taken at wk 2,8 , and 14 , and processed in the laboratory of the Dutch animal health service according to international standards (Hogan et al., 1999). Bacteriological culturing resulted in $42 \%$ of the samples having no growth, $30 \%$ with Staphylococcus, $19 \%$ with Bacillus, and a range of other bacteria with low incidence. For analysis, 3 categories were derived: bacteriology 1 (all bacteria other than Staphylococcus and Streptococcus, mainly Bacillus), bacteriology 2 (Staphylococcus and Streptococcus, mainly Staphylococcus), and bacteriology 3 (1 for samples with no bacteria, 0 otherwise). For bacteriology 1 and bacteriology 2 , possible values were 0 (no bacteria), 1 (few bacteria), 2 (not few nor many), and 3 (many bacteria).

\section{Statistical Methods}

The data from the experiment were analyzed with AS-REML (Gilmour et al., 2004). Treatment effects (and their interactions) were modeled as fixed effects: $\mathrm{MF}=$ effect of milking frequency (2 or 3 times daily); $\mathrm{RA}=$ effect of ration composition (low or high energy); and GG = effect of genetic group (high or low genetic merit for "Inet"). 
Table 3. Predicted mean milk production and components by treatment class (Beerda et al., 2007)

\begin{tabular}{llllllll}
\hline Treatment & Class & $\begin{array}{l}\text { Cows } \\
(\mathrm{n})\end{array}$ & $\begin{array}{l}\text { Milk } \\
(\mathrm{kg} / \mathrm{d})\end{array}$ & $\begin{array}{l}\text { Fat } \\
(\%)\end{array}$ & $\begin{array}{l}\text { Protein } \\
(\%)\end{array}$ & $\begin{array}{l}\text { Lactose } \\
(\%)\end{array}$ & $\begin{array}{l}\text { Urea } \\
(\mathrm{mg} / 100 \mathrm{~mL})\end{array}$ \\
\hline \multirow{2}{*}{ Genetic group } & Low & 44 & 24.1 & 4.27 & 3.13 & 4.72 & 24 \\
& High & 56 & 25.6 & 4.32 & 3.19 & 4.70 & 25 \\
Milking frequency & 2×/d & 50 & 23.3 & 4.40 & 3.25 & 4.73 & 25 \\
& 3×/d & 50 & 26.5 & 4.21 & 3.09 & 4.68 & 25 \\
Ration & Low energy & 50 & 20.9 & 4.38 & 3.05 & 4.63 & 25 \\
& High energy & 50 & 29.0 & 4.24 & 3.24 & 4.78 & 24 \\
\hline
\end{tabular}

Random components of the model accounted for the effect of repeated records on a cow. Spline functions were used to adjust for the effects of experimental week and lactation week by treatment. For traits that were scored for individual teats (teat condition and bacteriology) the effect of cow teat replaced the cow effect. Results presented here are the means $( \pm$ SEM) predicted by the described statistical model. In the results section, effects and differences between groups are reported only if significant $(P<0.05)$, unless explicitly stated otherwise.

\section{RESULTS}

\section{Milk Production and Milk Composition}

The results on milk production and milk composition are presented in detail in the companion article by Beerda et al. (2007) and are summarized in Table 3. Milk production levels were significantly increased by the $\mathrm{E}$ ration compared with the $\mathrm{S}$ ration. High genetic merit for milk production and 3 times daily milking increased milk production, but only in the heifers that received the E ration (data not shown). Fat and protein content were significantly lower in the milk of heifers that were milked 3 times a day compared with milk of heifers that were milked twice a day. The $\mathrm{S}$ ration caused reduced protein and lactose content. Urea levels in milk gradually increased (Table 4) from calving until wk 10 of lactation and declined thereafter for all treat- ments in a similar way (data not shown). Throughout the experimental period, significantly lower levels of urea were found in the milk of the animals on the $\mathrm{E}$ ration, but the average difference in urea between rations was small (Table 3).

\section{Udder Health Traits}

During the treatment period, 3 cases of clinical mastitis occurred, all for animals with high breeding values. Moreover, this did not indicate significant differences in udder health between treatments (Table 4). Actinomyces pyogenes was found in the bacteriological samples from the animals with mastitis.

Model predictions regarding $\ln (\mathrm{SCC})$ are given in Figure 2 . The effect of lactation week on $\ln (\mathrm{SCC})$ was significant for all treatment groups during the experimental period, and in general, gradually declined in the first $7 \mathrm{wk}$ after calving (Table 4). Milking frequency and genetic merit were significant experimental factors. Predicted mean values for treatment groups varied between $3.8 \pm 0.3$ in group 3SL and $5.1 \pm 0.2$ in group $2 \mathrm{SH}$. Three times daily milking resulted in significantly lower $\ln (\mathrm{SCC})(3.9 \pm 0.1)$ throughout the first $14 \mathrm{wk}$ of lactation than did twice daily milking $(4.3 \pm 0.1)$. Animals with a high breeding value for milk production (H heifers) had significantly higher $\ln (\mathrm{SCC})$ in the first 14 wk of lactation $(4.3 \pm 0.2)$ than did $\mathrm{L}$ heifers $(3.9 \pm 0.1)$; this difference was particularly notable for animals on

Table 4. Means $( \pm \mathrm{SE})$ and $P$-values $(P<0.05)$ for treatment factors and interactions on udder health traits

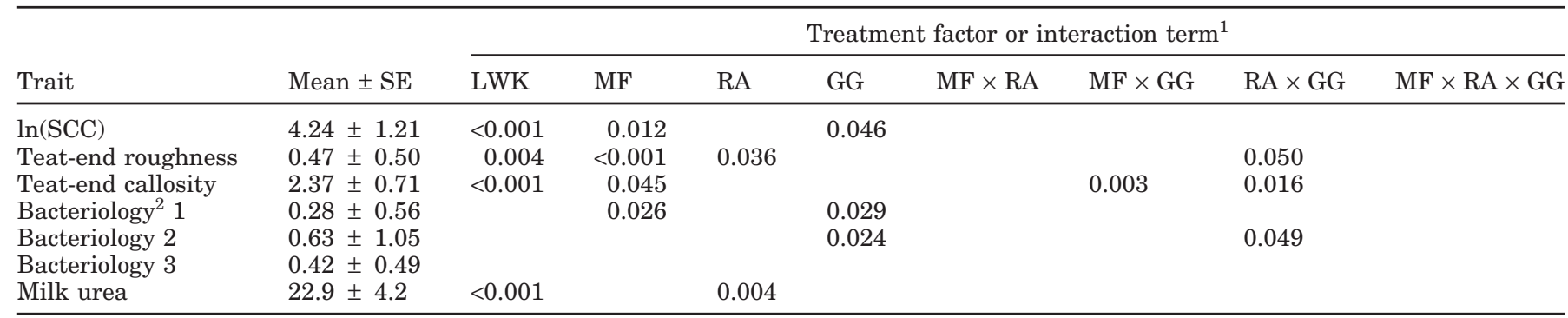

${ }^{1} \mathrm{LWK}=$ lactation week; $\mathrm{MF}$ = milking frequency; RA = ration; GG = genetic group. The other terms refer to interactions.

${ }^{2}$ Bacteriology class 1 = bacteriological culture revealing bacteria other than Staphylococcus and Streptococcus; Bacteriology $2=$ bacteriological culture revealing Staphylococcus or Streptococcus; Bacteriology 3 = bacteriological cultures with no growth. 


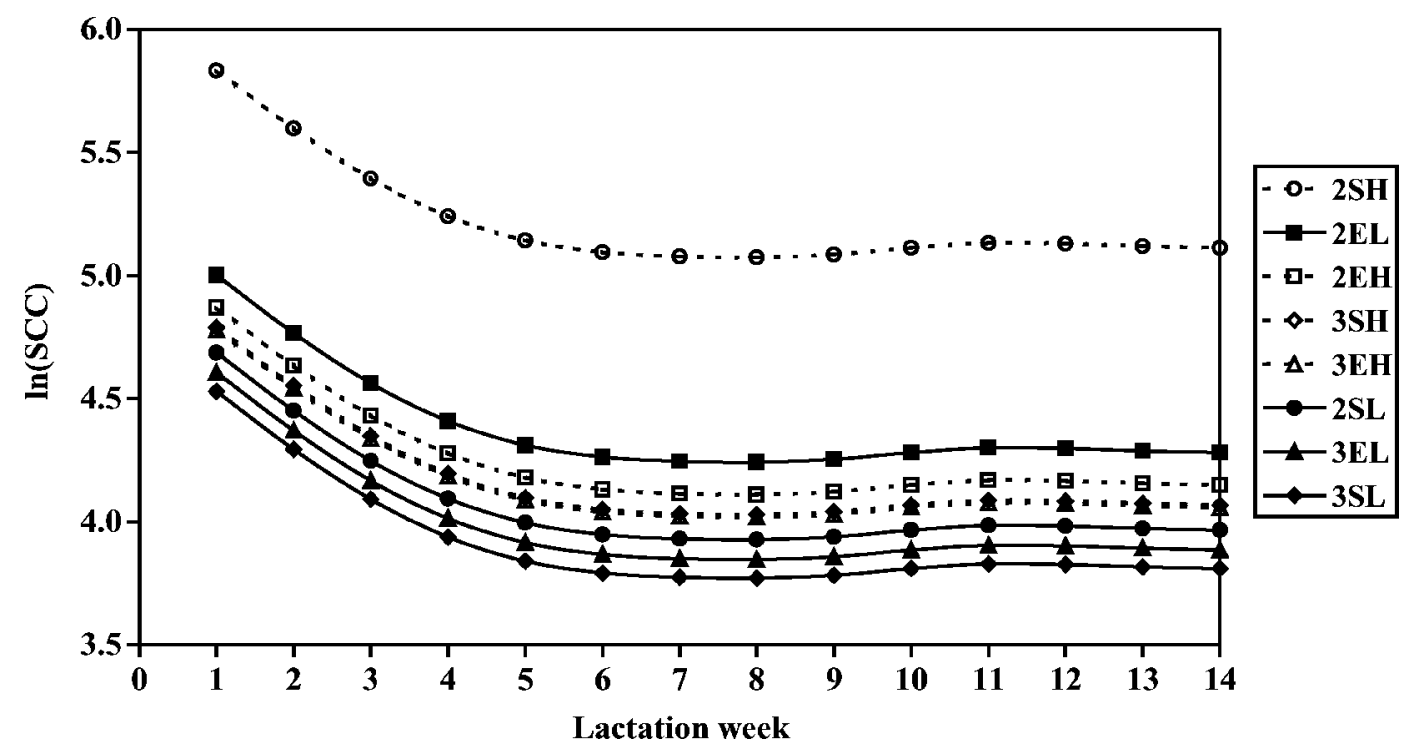

Figure 2. Predicted mean values for $\ln (\mathrm{SCC})$ during the first $14 \mathrm{wk}$ of lactation. Means are presented per experimental group; that is, combinations of milking frequency ( 2 or 3 times/d), feed quality (high $=\mathrm{E}$, low $=\mathrm{S}$ ), and genetic merit for milk production $($ high $=\mathrm{H}$, low = $\mathrm{L}) . \operatorname{Ln}(\mathrm{SCC})$ were significantly affected by lactation week, milking frequency, and genetic merit.

the $\mathrm{S}$ ration. The $2 \mathrm{SH}$ group of animals differed from the other treatment groups.

The teat conditions of the heifers were evaluated by teat-end roughness (Figure 3) and teat-end callosity (Figure 4). Roughness gradually increased for all treatments in the first $14 \mathrm{wk}$ of lactation. Predicted mean values varied between $0.38 \pm 0.05$ in group $2 \mathrm{EH}$ and $0.86 \pm 0.05$ in group $3 \mathrm{SH}$. Three-times-daily milking resulted in significantly higher teat end roughness ( 0.79 \pm 0.04 ) throughout the first 14 wk compared with twicedaily milking $(0.48 \pm 0.04)$. Differences between rations were significant, but small: animals on the $\mathrm{E}$ ration had lower roughness scores $(0.60 \pm 0.04)$ than the animals on $\mathrm{S}$ ration $(0.67 \pm 0.04)$. The difference between $\mathrm{E}$ and $\mathrm{S}$ was not significant for the $\mathrm{L}$ heifers $(0.64 \pm$ 0.05 vs. $0.65 \pm 0.05$ ), but was significant for the $\mathrm{H}$ heifers

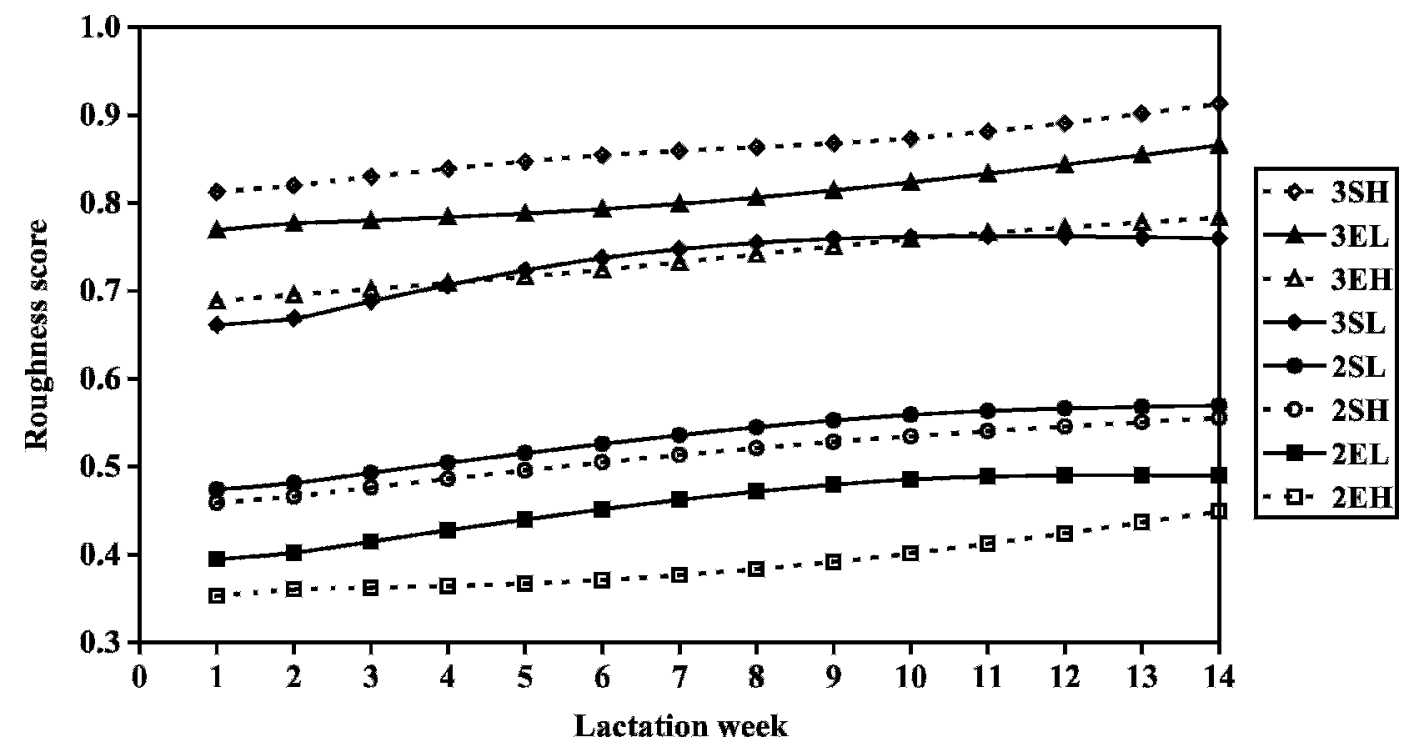

Figure 3. Model predictions for teat end roughness during the first 14 wk of lactation. Means are presented per experimental group; that is, combinations of milking frequency $(2$ or 3 times/d), feed quality (high $=\mathrm{E}$, low $=\mathrm{S}$ ), and genetic merit for milk production (high $=$ $\mathrm{H}$, low $=\mathrm{L}$ ). Teat-end roughness was significantly affected by lactation week, milking frequency, and ration. 


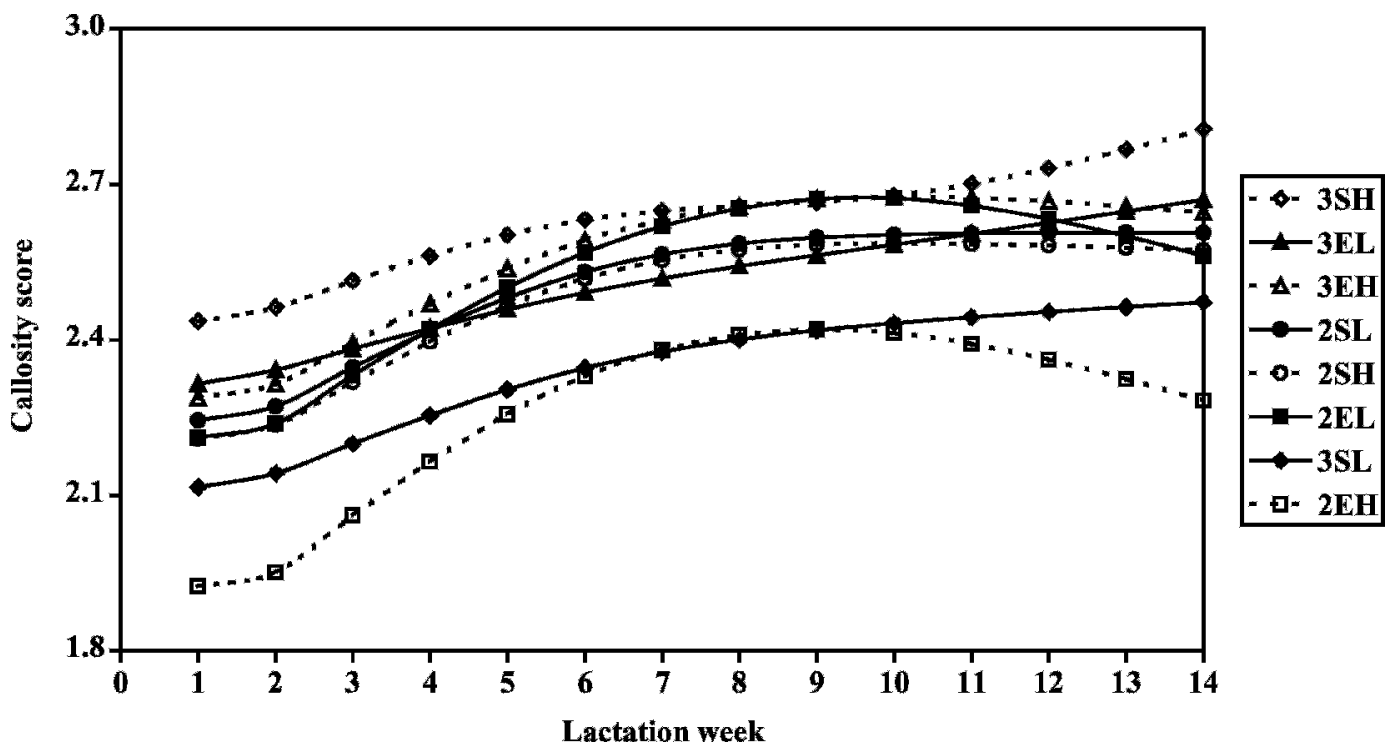

Figure 4. Model predictions for teat end callosity during the first $14 \mathrm{wk}$ of lactation. Means are presented per experimental group; that is, combinations of milking frequency ( 2 or 3 times/d), feed quality (high $=\mathrm{E}$, low $=\mathrm{S}$ ), and genetic merit for milk production (high $=\mathrm{H}$, low $=\mathrm{L}$ ). Teat-end callosity was significantly affected by lactation week, milking frequency, and interactions of milking frequency and ration with genetic group.

$(0.56 \pm 0.04$ vs. $0.69 \pm 0.04)$. Differences between 2 and 3-times-daily milking were observed at the first observation point and remained relatively constant during the experimental period.

Similar to teat-end roughness, teat-end callosity changed with lactation stage (Figure 4). After 8 to 10 wk, a maximum score was reached for the animals milked twice daily. For heifers that were milked three times daily, the increase in callosity continued throughout the first 14 wk of lactation. Predicted mean values varied between $2.40 \pm 0.10$ in group 3SL and $2.66 \pm$ 0.09 in group $3 \mathrm{SH}$. Although the animals milked 3 times daily had significantly higher callosity, the difference was small. Differences were most apparent in the first and last weeks of lactation. The effect of interaction of milking frequency and genetic groups showed that the predicted mean for $2 \mathrm{~L}(2.62 \pm 0.08)$ animals was higher than that for $3 \mathrm{~L}(2.47 \pm 0.08)$ animals, whereas the predicted mean for group $2 \mathrm{H}(2.49 \pm 0.07)$ was lower than that for group $3 \mathrm{H}(2.66 \pm 0.08)$. An interaction was found for ration by genetic group, with higher predicted callosity for $\mathrm{E}(2.60 \pm 0.08)$ vs. $\mathrm{S}(2.49 \pm 0.08)$ for $\mathrm{L}$ heifers and lower callosity for $\mathrm{E}(2.53 \pm 0.07)$ vs. S (2.61 \pm 0.08 ) for $\mathrm{H}$ heifers.

At wk 2, 8, and 14 of lactation, quarter milk samples were taken for bacteriological culturing and determination of cell counts. For heifers milked 3 times daily, more bacteria other than Staphylococcus and Streptococcus were found in the milk samples than for heifers milked twice daily $(0.36 \pm 0.05$ vs. $0.29 \pm 0.05)$. In the samples from $\mathrm{H}$ heifers, less of these bacteria were found $(0.28 \pm 0.04$ vs. $0.38 \pm 0.05$ for L heifers). For bacteria of category 2 (Staphylococcus and Streptococcus), significantly more bacteria were found in samples from $H$ heifers $(0.39 \pm 0.08)$ than from $L$ heifers $(0.18$ \pm 0.09 ), but this difference was mainly caused by differences between $\mathrm{L}$ and $\mathrm{H}$ heifers on the $\mathrm{S}$ ration $(0.12 \pm$ 0.12 vs. $0.51 \pm 0.10)$ and was not significant on the E ration $(0.24 \pm 0.11$ vs. $0.27 \pm 0.10)$. There were no significant differences between treatment groups in the overall occurrence of negative cultures, as indicated by the results for the bacteriology 3 category.

\section{DISCUSSION}

The aim of this study was to estimate possible risks of udder health problems in relation to milk production level and potential interactions between genetics and management factors. Heifers with low or high genetic merit for milk production were exposed to experimental factors that were expected to create substantial differences in milk production and that modeled different management strategies that can occur on commercial farms. This allowed us to assess the effects of genotype, environment, and $\mathrm{G} \times \mathrm{E}$ interactions in relation to milk production and animal health. Results regarding resource allocation, blood metabolites, immune parameters, hormones, and enzymes are reported elsewhere (Beerda et al., 2005, 2007). As described by Beerda et al. (2007), all experimental factors affected milk produc- 
tion as expected, but influenced $\mathrm{EB}$ in various ways. The E ration stimulated milk production, and resulted in improved EB. In contrast, impaired EB was associated with increased milk production for milking frequency and genetic merit.

Negative relationships between lactose concentration and udder health are reported (Bansal et al., 2005), suggesting that low lactose content is basically an indication of udder infection. The decreased lactose concentration in case of udder inflammation is due to increased leakage of salts that cause osmotic pressure. Such infection will cause an increased SCC; therefore, low lactose concentration is correlated with increased SCC. Cell counts are preferred as an indicator of udder health; therefore, lactose content, although analyzed in milk samples, is usually not reported to farmers. In our study, ration did not influence $\mathrm{SCC}$, but heifers on the $\mathrm{E}$ ration had a more positive $\mathrm{EB}$ and higher lactose content throughout the experimental period (Beerda et al., 2007). This agrees with results of Schei et al. (2005), who indicated a positive relationship between milk lactose and EB, suggesting that lactose content is not only an indicator of udder health, but is also affected by EB and could be a useful management tool.

\section{Udder Health}

Ration. Ration had minimal effects on the udder health traits, though $\mathrm{H}$ heifers on the $\mathrm{E}$ ration had lower roughness scores than $\mathrm{H}$ heifers on the $\mathrm{S}$ ration (0.56 vs. 0.69). This agrees with Collard et al. (2000), who found no relationships between EB and udder health, and Sehested et al. (2003), who found no associations between concentrate supplementation level and health. Similarly, Kornalijnslijper et al. (2003) concluded that host resistance to experimentally induced Escherichia coli mastitis was not affected by production level or feeding regimen. This suggests that improving EB through ration formulation (Beerda et al., 2007) is not beneficial for udder health or that restricting milk production by restricting energy intake does not impair udder health. This is somewhat unexpected, because Beerda et al. (2005) found a reduced immune response in heifers on the S ration. Moreover, it concurs with unchanged neutrophil function as measured by reactive oxygen species production. It should be noted at this point that our objective was to test rations that differed in energy content, but which did not introduce any other imbalances. Therefore, the $\mathrm{E}$ ration had higher protein content. If lower energy content is accompanied by inadequate mineral supply, imbalances between fat and protein, or protein deficiency, other results can be expected. Despite the lower protein content of the $\mathrm{S}$ ration, the animals on this ration had higher urea levels in their milk. This is likely due to mobilization of body tissue.

Milking Frequency. This experiment showed that milking frequency affected SCC, teat condition, and bacteriology, but not in the same way. This indicates that milking 3 times daily has both positive and negative effects on udder health compared with twice-daily milking. In our study, 3-times daily milking lowered SCC, which is in agreement with other literature (Waterman et al., 1983; Smith et al., 2002). Dahl et al. (2004) found a beneficial effect of milking 6 times compared with 3 times daily in the first $21 \mathrm{~d}$ of lactation, and reported that the beneficial effect remains even after cessation of the higher milking frequency. Although a decrease in SCC is generally regarded as an indication of improved udder health, Waterman et al. (1983) concluded that milking frequency did not affect overall udder health. This conclusion was based on the absence of significant differences in new infections for cows milked 2 or 3 times daily despite the difference in SCC.

To be infected, udder quarters have to be penetrated by pathogens through the teat canal, usually bacteria. Therefore, teats can be regarded as the first line of defense. The defense operates both through the sphincter muscle and keratin in the teat canal (Neijenhuis, 2004). In our study, 3 times daily milking impaired teat condition compared with twice-daily milking, and therefore, could have increased infection risk. The negative impact of increased milking frequency on teat condition is consistent with results of Neijenhuis (2004), who reported that machine-on time was a risk factor. In none of the treatments did teat-end roughness stabilize within 14 wk of lactation, whereas callosity was at its maximum 8 to $10 \mathrm{wk}$ after calving. Neijenhuis et al. (2000) reported an increase of both roughness and callosity during the first $14 \mathrm{wk}$ of lactation for cows milked twice daily. Moreover, the majority of the increase was realized within 8 wk after calving. Neijenhuis (2004) reported that technical functioning of the milking machine influenced teat condition. Given the increased machine-on time with more frequent milking proper functioning of the milking equipment will be of extra importance with more frequent milking. As is clear from Figure 3, the effect of milking frequency on teat-end roughness was already present in the second week of treatment and did not change much thereafter. Because of the limited duration of the experiment, the impaired teat condition may not have resulted in more infections. If the unfavorable effects of frequent milking on teat condition disappear after lowering milking frequency, but the positive effects on production and SCC remain throughout the lactation as reported by Dahl et al. (2004), increasing milking frequency in early lactation 
could be a good management strategy to improve udder health. A further beneficial effect of more frequent milking could be reduced milk leakage.

Genetic Merit. This study indicated that heifers with high genetic merit for milk production had higher cell counts $(75,000$ vs. 52,000 cells $/ \mathrm{mL}$ of milk for the $\mathrm{H}$ and $\mathrm{L}$ groups, respectively). Estimates of $\ln (\mathrm{SCC})$ were $4.31 \pm 0.14$ for $\mathrm{H}$ heifers and $3.95 \pm 0.16$ for $\mathrm{L}$ heifers. This result agrees with unfavorable genetic correlations between production and udder health of Carlen et al. (2004) and Koivula et al. (2005). Restrictions were not placed on expected breeding values for traits other than production (i.e., Inet) when selecting the animals for our experiment. The sires of the L heifers in our experiment had slightly higher average EBV for udder health (101.0 vs. 99.3) and stayability (105.0 vs. 102.0) than the sires of the $H$ heifers. Differences between management groups within genetic lines in average sire EBV for udder health were very small. The absence of an effect of ration indicates that the animals with high genetic merit still have the capacity to adapt, for example to low energy supply, by limiting their production. This agrees with results of Knight et al. (2004), who concluded that heifers with high genetic merit for milk production were not more susceptible to metabolic disturbances and did not have different metabolic safety margins than low genetic merit herdmates.

Results from this study with regard to effects of genetic merit on bacteriology were not straightforward. Overall genetic merit was not related to the percentage of cultures without bacteria, but high genetic merit heifers seemed more susceptible to infection with Staphylococcus and less susceptible to infection with Bacillus and other environmental pathogens. The difference in pathogens might have affected the SCC differences. Kornalijnslijper et al. (2003) concluded that host resistance in an infection trial was not affected by production-level differences in the previous lactation under the same management conditions, but Windig et al. (2005) concluded that high-producing cows in highproducing herds have increased risk for elevated SCC, although these herds have lower SCC. It is generally assumed that increased SCC are not likely to represent an increased ability to resist invading pathogens (Coffey et al., 1986), but are mainly caused by pathogens in the udder (Harmon, 1994). According to Beaudeau et al. (2002), herds with low SCC may have specific risks for clinical mastitis. These studies indicate that cows with high genetic merit for milk production have normally functioning immune systems, but they may be more susceptible to pathogens that have large effects on SCC.

$\boldsymbol{G} \times \boldsymbol{E}$ Interaction. For milk production in this experiment, $\mathrm{G} \times \mathrm{E}$ interaction was present as described by
Beerda et al. (2007). Some indications for G×E interactions for udder health traits were found in this study. For teat condition, some interaction terms of $\mathrm{G} \times \mathrm{E}$ were significant, but difficult to interpret. Heifers in the $\mathrm{H}$ group had significantly lower teat-end roughness on the $\mathrm{E}$ ration, whereas for $\mathrm{L}$ heifers, there was no difference between rations. Moreover, $\mathrm{H}$ heifers had significantly lower callosity on the $\mathrm{E}$ ration, but the difference between rations was reversed for the $\mathrm{L}$ heifers

\section{Milk Production Level and Udder Health}

In general, it can be concluded that animals with high genetic merit for production have higher SCC than animals with low genetic merit for production, possibly as a result of sensitivity to different bacteria. Despite the low heritability of health traits, ignoring these traits in selection programs results in a slow but steady deterioration of udder health. Because of the negative correlation, high-producing cows within herds have an increased risk of getting mastitis. This risk is further increased with continued selection for higher milk production unless selection against mastitis is included in selection strategies (Ingvartsen et al., 2003). Although herd management has a large influence on udder health (thus providing opportunities to combine high production with good udder health), maintaining health and high production will require increased skills and time from the farmer. This is contradictory to the trend on many farms to increase labor efficiency and herd size. As this study indicates, adjusting feeding levels will not help to prevent problems. Because breeding values for udder health are available now in several countries, the unfavorable genetic trend can be changed through proper selection.

An important feature of this experiment is that it was carried out with heifers during a limited time span. The main advantage of the use of heifers was that these animals have no history of disease and are a relatively uniform group compared with older cows. None of the animals in this experiment suffered from health problems that could be related to the experimental factors, and physiological variables were typically within the range of values expected in healthy cows, but a high milk production did increase metabolic rate as indicated by higher levels of $\mathrm{pCO}_{2}$, glutamate dehydrogenase, and heart rate (Beerda et al., 2005). The duration of the experiment may have been too short to show negative effects of the increased metabolic rate, but it could be questioned if cows generally live long enough to experience such effects. Heifers are generally less sensitive to metabolic diseases than older cows, but they may show physiological indications of metabolic load more readily (Beerda et al., 2005). 


\section{CONCLUSIONS}

Three-times-daily milking, feeding high quality TMR, and high genetic merit for milk production all stimulated milk production level. Of these experimental factors, ration composition had the largest effect on milk production. Milking frequency, ration composition, and genetic merit differed in their effects on udder health measures, mirroring the complexity of relationships between milk production level and udder health. Ration composition did not affect SCC or bacterial IMI and had minor effects on teat condition, although cows that received low quality rations had rougher teat ends. This indicates that satisfactory udder health is possible with high milk production and that high production is not a major risk factor for udder health in the first lactation. Higher milking frequency generally improved SCC, but impaired teat condition and did not clearly influence bacteriological status. High genetic merit did not affect teat condition, but was related to higher SCC, more Staphylococcus, and less Bacillus and other environmental pathogens in cultures. This suggests that heifers with high genetic merit for production are more susceptible to pathogens with a large effect on SCC. The effects of milking frequency and feeding on udder health were similar for cows with high and low genetic merit. However, high genetic merit cows seemed slightly more sensitive to low energy supply than low genetic merit cows. Genetic selection on milk production without taking udder health into account will cause increased sensitivity for udder health problems. Maintaining good udder health will then require increased skills and time of dairy farmers who have to divide their attention over more cows as a result of increasing farm sizes. Therefore, future genetic selection should take health traits into account.

\section{ACKNOWLEDGMENTS}

This study was financially supported by the Ministry of Agriculture, Nature and Food Quality (Programma 414 "Maatschappelijk verantwoorde veehouderij"). John Hickey is thanked for his linguistic review of the paper.

\section{REFERENCES}

Bansal, B. K., J. Hamann, N. Th. Grabowski, and K. B. Singh. 2005. Variation in the composition of selected milk fraction samples from healthy and mastitic quarters, and its significance for mastitis diagnosis. J. Dairy Res. 72:144-152.

Beaudeau, F., C. Fourichon, H. Seegers, and N. Bareille. 2002. Risk of clinical mastitis in dairy herds with a high proportion of low individual milk somatic cell counts. Prev. Vet. Med. 53:43-54.

Beaudeau, F., A. Henken, C. Fourichon, K. Frankena, and H. Seegers. 1993. Associations between health disorders and culling of dairy cows: A review. Livest. Prod. Sci. 35:213-236.
Beerda, B., W. Ouweltjes, L. B. J. Sěbek, J. J. Windig, and R. F. Veerkamp. 2007. Effects of genotype by environment interactions on milk yield, energy balance, and protein balance. J. Dairy Sci. 90:219-228.

Beerda, B., W. Ouweltjes, J. J. Windig, M. P. L. Calus, and R. F. Veerkamp. 2005. Dairy cow health and the effects of genetic merit for milk production, management and interactions between these: Blood metabolites and enzymes. Page 245 in Proc. 56th Annu. Mtg. EAAP, Uppsala, Sweden. EAAP, Rome, Italy.

Carlen, E., E. Strandberg, and A. Roth. 2004. Genetic parameters for clinical mastitis, somatic cell score, and production in the first three lactations of Swedish Holstein cows. J. Dairy Sci. 87:3062-3070.

Coffey, E. M., W. E. Vinson, and R. E. Pearson. 1986. Potential of somatic cell concentration in milk as a sire selection criterion to reduce mastitis in dairy cattle. J. Dairy Sci. 69:2163-2172.

Collard, B. L., P. J. Boettcher, J. C. M. Dekkers, D. Petitclerc, and L. R. Schaeffer. 2000. Relationships between energy balance and health traits of dairy cattle in early lactation. J. Dairy Sci. 83:2683-2690.

Dahl, G. E., R. L. Wallace, R. D. Shanks, and D. Lueking. 2004. Hot Topic: Effects of frequent milking in early lactation on milk yield and udder health. J. Dairy Sci. 87:882-885.

Dillon, P., D. P. Berry, R. D. Evans, F. Buckley, and B. Horan. 2005. Consequences of genetic selection for increased milk production in European seasonal pasture based systems of milk production. Livest. Prod. Sci. 99:141-158.

Gilmour, A. R., B. R. Cullis, S. J. Welham, and R. Thompson. 2004. ASREML Reference Manual, 2nd ed. (draft 1.62). NSW Agricultural Biometrical Bulletin 3, NSW Department of Primary Industries, Orange, Australia.

Harmon, R. J. 1994. Physiology of mastitis and factors affecting somatic cell counts. J. Dairy Sci. 77:2103-2112.

Hogan, J. S., R. N. Gonzalez, R. J. Harmon, S. C. Nickerson, S. P. Oliver, J. W. Pankey, and K. L. Smith. 1999. Laboratory Handbook on Bovine Mastitis. Rev. ed. National Mastitis Council, Madison, WI.

Ingvartsen, K. L., R. J. Dewhurst, and N. C. Friggens. 2003. On the relationship between lactational performance and health: Is it yield or metabolic imbalance that causes production diseases in dairy cattle? A position paper. Livest. Prod. Sci. 83:277-308.

Knight, C. H., M. A. Alamer, A. Sorensen, I. M. Nevison, D. J. Flint, and R. G. Vernon. 2004. Metabolic safety margins do not differ between cows of high and low genetic merit for milk production. J. Dairy Res. 71:141-153.

Koivula, M., E. A. Mantysaari, E. Negussie, and T. Serenius. 2005. Genetic and phenotypic relationships among milk yield and somatic cell count before and after clinical mastitis. J. Dairy Sci. 88:827-833.

Kornalijnslijper, J. E., B. Beerda, A. J. J. M. Daemen, J. T. N. Van der Werf, T. Van Werven, T. A. Niewold, V. P. M. G. Rutten, and E. N. Noordhuizen-Stassen. 2003. The effect of milk production level on host resistance of dairy cows, as assessed by the severity of experimental Escherichia coli mastitis. Vet. Res. 34:721-736.

Neijenhuis, F. 2004. Teat condition in dairy cows. PhD Thesis, Utrecht University, Utrecht, the Netherlands.

Neijenhuis, F., H. W. Barkema, H. Hogeveen, and J. P. T. M. Noordhuizen. 2000. Classification and longitudinal examination of callused teat ends in dairy cows. J. Dairy Sci. 83:2795-2804.

NRS. 2004. Annual statistics 2004. Dutch Cattle Syndicate, Arnhem, the Netherlands.

Oltenacu, P. A., and B. Algers. 2005. Selection for increased production and the welfare of dairy cows: Are new breeding goals needed? Ambio 34:311-315.

Schei, I., H. Volden, and L. Baevre, L. 2005. Effects of energy balance and metabolizable protein level on tissue mobilization and milk performance of dairy cows in early lactation. Livest. Prod. Sci. 95:35-47.

Sehested, J., T. Kristensen, and K. Søegaard. 2003. Effect of concentrate supplementation level on production, health and efficiency in an organic dairy herd. Livest. Prod. Sci. 80:153-165. 
Smith, J. W., L. O. Ely, W. M. Graves, and W. D. Gilson. 2002. Effect of milking frequency on DHI performance measures. J. Dairy Sci. 85:3526-3533.

van der Beek, S. 2000. Breeding for profit in the Netherlands. Online: www-interbull.slu.se/bulletins/bulletin23/beek.pdf Accessed Mar. 30, 2006.

Veerkamp, R. F., B. Beerda, and T. van der Lende. 2003. Effects of genetic selection for milk yield on energy balance, levels of hormones, and metabolites in lactating cattle, and possible links to reduced fertility. Livest. Prod. Sci. 83:257-275.

Waterman, D. F., R. J. Harmon, R. W. Hemken, and B. E. Langlois. 1983. Milking frequency as related to udder health and milk production. J. Dairy Sci. 66:253-258.

Windig, J. J., M. P. L. Calus, and R. F. Veerkamp. 2005. Influence of herd environment on health and fertility and their relationship with milk production. J. Dairy Sci. 88:335-347. 